\title{
Parallel Inhibition of Islet Glucokinase and Glucose-Stimulated Insulin Secretion by Either Alloxan or Ninhydrin
}

\author{
Ichitomo Mrwa, Hiroshi Hara, and Jun OKudA* \\ Department of Clinical Biochemistry, Faculty of Pharmacy, \\ Meijo University, Nagoya 468, Japan
}

(Received April 21, 1986)

\begin{abstract}
Summary Treatment of pancreatic islets with alloxan or ninhydrin at concentrations that induced the inhibition of glucokinase activity similarly inhibited glucose-stimulated insulin secretion. Alloxan- or ninhydrininduced inhibition of glucokinase activity was blocked by the presence of hexoses, which also protected against the inhibitory effect of each drug on insulin secretion. The protective effect of D-glucose against the inhibition of glucokinase activity by alloxan or ninhydrin showed $\alpha$-anomeric preference, which was similarly observed in the protection by the sugar against the inhibition of insulin secretion. These results suggest that the inhibition of glucose-stimulated insulin secretion by treatment of pancreatic islets with alloxan or ninhydrin is due to the inhibition of glucokinase.
\end{abstract}

Key Words: glucokinase, insulin secretion, alloxan, ninhydrin, pancreatic islet

Many lines of evidence suggest that glucokinase (ATP: D-glucose 6-phosphotransferase, EC 2.7.1.2) is positioned to regulate glucose metabolism in pancreatic islets and is consequently involved in glucose-stimulated insulin release [1-5]. For instance, glucose phosphorylation by islet glucokinase and glucose-induced insulin release show parallel and sigmoidal concentration dependency for glucose $[1,2]$. Moreover, both glucokinase [3, 6] and glucose-stimulated insulin release [7] display a preference for the $\alpha$ anomer of D-glucose. Malaisse and his colleagues, however, pointed out the participation of regulatory sites distal to glucose phosphorylation in the control of both glucose metabolism and insulin release [8, 9]. Thus, whether glucokinase plays a critical role in relating islet glycolysis to insulin release is the subject of controversy.

On the other hand, a brief exposure of pancreatic islets to alloxan $[10,11]$ or

\footnotetext{
*To whom correspondence should be addressed.
} 
to ninhydrin $[12,13]$ is known to inhibit the subsequent glucose-induced insulin release. The mechanisms by which alloxan and ninhydrin exert their inhibitory effects remain unclear.

Considering these facts, we hypothesized that both alloxan and ninhydrin might inhibit islet glucokinase. The purpose of this study was to verify this hypothesis and thereby to fortify the view that islet glucokinase serves as the key enzyme translating extracellular glucose into insulin secretion.

\section{MATERIALS AND METHODS}

Reagents. Collagenase (type IV), bovine serum albumin (fraction V), and alloxan monohydrate were all purchased from Sigma Chemical Co. Glucose 6phosphate dehydrogenase (from Leuconostoc mesenteroides) was obtained from Oriental Yeast Co., Ltd., and ninhydrin was from Wako Pure Chemical Industries, Ltd. All other reagents were of the highest grade commercially available.

Islet isolation. Fed male Sprague-Dawley rats weighing 250-350 g were used. Islets were isolated by collagenase digestion of the pancreas [14].

Treatment of islets. After isolation, islets were placed at the bottom of 1.5 $\mathrm{ml}$ plastic centrifuge tubes which were fitted into a microfuge (Kubota Seisakusho, Tokyo; model KM-15200). Then, $160 \mu$ of treatment buffer $(137 \mathrm{mM} \mathrm{NaCl}, 5.4$ $\mathrm{mm} \mathrm{KCl}, 0.34 \mathrm{~mm} \mathrm{Na} \mathrm{HPO}_{4}, 0.44 \mathrm{~mm} \mathrm{KH}_{2} \mathrm{PO}_{4}, 0.41 \mathrm{~mm} \mathrm{MgSO}, 0.49 \mathrm{~mm} \mathrm{MgCl}$, $1.26 \mathrm{mM} \mathrm{CaCl}_{2}, 4.2 \mathrm{mM} \mathrm{NaHCO}, 0.2 \mathrm{mg} / \mathrm{ml}$ bovine serum albumin, and $2.8 \mathrm{~mm}$ glucose, $\mathrm{pH} 7.4)$ equilibrated with a mixture of $\mathrm{O}_{2}(95 \%)$ and $\mathrm{CO}_{2}(5 \%)$ was added, and the islets were preincubated at $37^{\circ} \mathrm{C}$ for $1 \mathrm{~min}$. After preincubation, $20 \mu \mathrm{l}$ of either treatment buffer or hexose solution (in treatment buffer) and $20 \mu \mathrm{l}$ of alloxan (or ninhydrin) solution in ice-cold saline were successively put into the tubes. The tubes were vortexed and islets were incubated in a final volume of $200 \mu$ in a Dubnoff metabolic shaking bath at $37^{\circ} \mathrm{C}$ and 80 oscillations/min for $5 \mathrm{~min}$. In experiments involving hexoses, the hexose solution was added just before addition of alloxan (or ninhydrin). Incubations were terminated by addition of $1.3 \mathrm{ml}$ of icecold treatment buffer. After centrifugation at $180 \times g$ for $1 \mathrm{~min}$, the medium was removed. Islets were washed once with $1.5 \mathrm{ml}$ of the same buffer, and the washed islets were immediately used for the assay of insulin secretion or glucose phosphorylation (glucokinase and hexokinase activities).

Assay of insulin secretion. Batches of six islets were placed in each of a series of $10 \times 75-\mathrm{mm}$ glass tubes and incubation was begun by addition of $500 \mu \mathrm{l}$ of Krebs-Ringer bicarbonate (KRB) buffer, equilibrated to $\mathrm{pH} 7.4$ with a mixture of $\mathrm{O}_{2}(95 \%)$ and $\mathrm{CO}_{2}(5 \%)$, containing $2 \mathrm{mg} / \mathrm{ml}$ bovine serum albumin and 16.7 $\mathrm{mm}$ glucose. For measurement of the basal rate of insulin secretion, $500 \mu \mathrm{l}$ of KRB buffer containing $2 \mathrm{mg} / \mathrm{ml}$ bovine serum albumin and $2.8 \mathrm{~mm}$ glucose was added instead. The incubations were performed at $37^{\circ} \mathrm{C}$ for $40 \mathrm{~min}$ in an atmosphere of a mixture of $\mathrm{O}_{2}(95 \%)$ and $\mathrm{CO}_{2}(5 \%)$. After incubation, samples of medium were taken and stored at $-70^{\circ} \mathrm{C}$ until the insulin assay could be conducted. 
Insulin was assayed by radioimmunoassay with the use of Sepharose-coupled antibody (Phadeseph insulin RIA, Pharmacia Co.), with human insulin as the standard.

Assays of glucokinase and hexokinase. Activities of glucokinase and hexokinase in pancreatic islets were assayed by a modification of the method of Trus et al. [15]. About 20 islets were sonicated in $290 \mu$ of sonication buffer, consisting of $30 \mathrm{~mm}$ Tris- $\mathrm{HCl}\left(\mathrm{pH}\right.$ 8.2), $4 \mathrm{~mm}$ EDTA, $150 \mathrm{~mm} \mathrm{KCl}, 4 \mathrm{~mm} \mathrm{MgCl}_{2}, 5 \mathrm{~mm} 2-$ mercaptoethanol, $3 \mathrm{~mm} \mathrm{KH} \mathrm{KH}_{4}, 1 \mathrm{mM} \mathrm{K}_{2} \mathrm{SO}_{4}$, and $2 \mathrm{mg} / \mathrm{ml}$ bovine serum albumin, in a $1.5 \mathrm{ml}$ plastic centrifuge tube cooled in ice water. For this purpose a series of 15 pulses ( 1 pulse/s) by a sonicator (Ohtake Works, Tokyo; model 5203) set on a power output of 50 watts were delivered. The sonicate was centrifuged at $15,000 \times g$ for $15 \mathrm{~min}$. Then a $120 \mu \mathrm{l}$ sample of each supernatant was added to 150 $\mu l$ of the assay reagent consisting of $100 \mathrm{~mm}$ Tris- $\mathrm{HCl}(\mathrm{pH} 8.0), 100 \mathrm{~mm} \mathrm{KCl}, 10$ $\mathrm{mm} \mathrm{MgCl}, 0.5 \mathrm{~mm} \mathrm{NAD}, 5 \mathrm{~mm} \mathrm{ATP}, 2 \mathrm{mg} / \mathrm{ml}$ bovine serum albumin, and 1 unit/ $\mathrm{ml}$ glucose 6-phosphate dehydrogenase. The reaction was started by addition of $30 \mu \mathrm{l}$ of glucose solution to achieve a glucose concentration of 0.5 or $50 \mathrm{~mm}$. Incubations were performed at $37^{\circ} \mathrm{C}$ for $90 \mathrm{~min}$ and stopped by addition of $0.7 \mathrm{ml}$ of $500 \mathrm{~mm}$ sodium phosphate buffer ( $\mathrm{pH} 7.0$ ) containing $0.42 \mathrm{~mm}$ sodium dodecylsulfate. Fluorescence of NADH was then measured. All the assays had reagent blanks. These consisted of the assay reagents with each glucose level and were incubated in the absence of the supernatant. The reagent blanks were subtracted from the total fluorescence of corresponding complete reaction mixtures. The hexokinase activity was measured at a glucose concentration of $0.5 \mathrm{~mm}$, and the glucokinase activity was estimated as the difference between activities at 0.5 and $50 \mathrm{~mm}$ glucose.

Statistics. Statistical analysis was performed using Student's $t$-test.

\section{RESULTS}

Treatment of pancreatic islets with alloxan $(0-500 \mu \mathrm{M})$ at $37^{\circ} \mathrm{C}$ for $5 \mathrm{~min}$ inhibited both glucokinase activity (Fig. 1A) and glucose-induced insulin secretion (Fig. 1B) in a concentration-dependent manner and to a comparable degree. Ninhydrin treatment $(0-100 \mu \mathrm{M})$ of islets also produced concentration-dependent inhibitions of both glucokinase activity (Fig. 2A) and insulin secretion (Fig. 2B), and again the two inhibitions were comparable. However, there was no significant inhibition of hexokinase activity at concentrations of either alloxan up to 500 $\mu \mathrm{M}$ or ninhydrin up to $100 \mu \mathrm{M}$ (data not shown).

The abilities of various hexoses $(15 \mathrm{~mm})$ to protect against the inhibitory effect of alloxan $(500 \mu \mathrm{M})$ on glucokinase activity and on glucose-induced insulin release are shown in Tables 1 and 2, respectively; and those of ninhydrin (100 $\mu \mathrm{M})$, in Tables 3 and 4, respectively. Glucokinase activity was inhibited by 76 and $78 \%$ by treatment of pancreatic islets with alloxan $(500 \mu \mathrm{M})$ and ninhydrin $(100$ $\mu \mathrm{M})$, respectively, in the absence of hexose. The inhibitory effects of both alloxan 

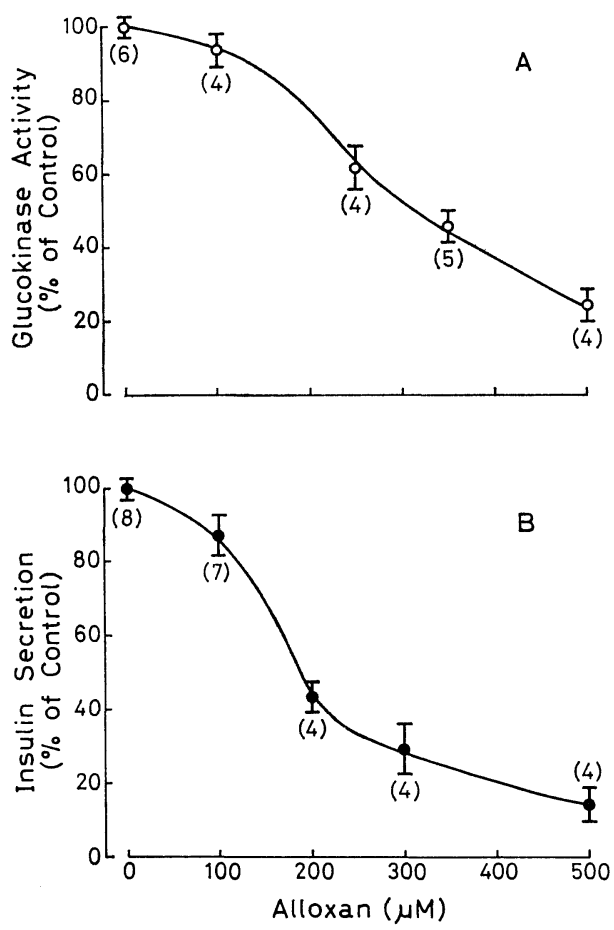

Fig. 1. Effect of alloxan concentration on islet glucokinase activity (A) and glucose-stimulated insulin secretion (B). Islets were treated with various concentrations of alloxan for $5 \mathrm{~min}$ at $37^{\circ} \mathrm{C}$ and then assayed for glucokinase activity and insulin secretion. Data are expressed as the mean percentage $\pm \mathrm{SD}$ of the glucokinase activity and insulin secretion in control islets. The activities of glucokinase and insulin secretion in control islets were $85.2 \pm 2.1 \mathrm{pmol} / \mathrm{h} /$ islet $(n=6)$ and $38.2 \pm 1.5 \mu \mathrm{U} / 40 \mathrm{~min} /$ islet $(n=8)$, respectively.

and ninhydrin on glucokinase activity were significantly blocked by D-glucose and D-mannose, but not by D-galactose. 3-O-Methyl-D-glucose was also effective in protecting against alloxan action, but not against ninhydrin action. Moreover, $\alpha$-D-glucose showed significantly greater protection against the inhibition of glucokinase by alloxan or ninhydrin than $\beta$-D-glucose. The protective effect of equilibrated D-glucose was between those of $\alpha$ - and $\beta$-D-glucose.

Glucose-induced insulin secretion was inhibited by 83 and $91 \%$ by the treatment of pancreatic islets with alloxan $(500 \mu \mathrm{M})$ and ninhydrin $(100 \mu \mathrm{M})$, respectively, in the absence of hexose. The inhibition of glucose-induced insulin release by alloxan was again blocked by the presence of D-glucose, D-mannose, or 3-Omethyl-D-glucose. The relative protective effects of the three hexoses were comparable with those in preventing alloxan-induced inhibition of glucokinase activity. There was a close similarity between the relative protective effects of hexoses on ninhydrin-induced inhibition of glucokinase activity and on ninhydrin-induced inhibition of insulin release. 

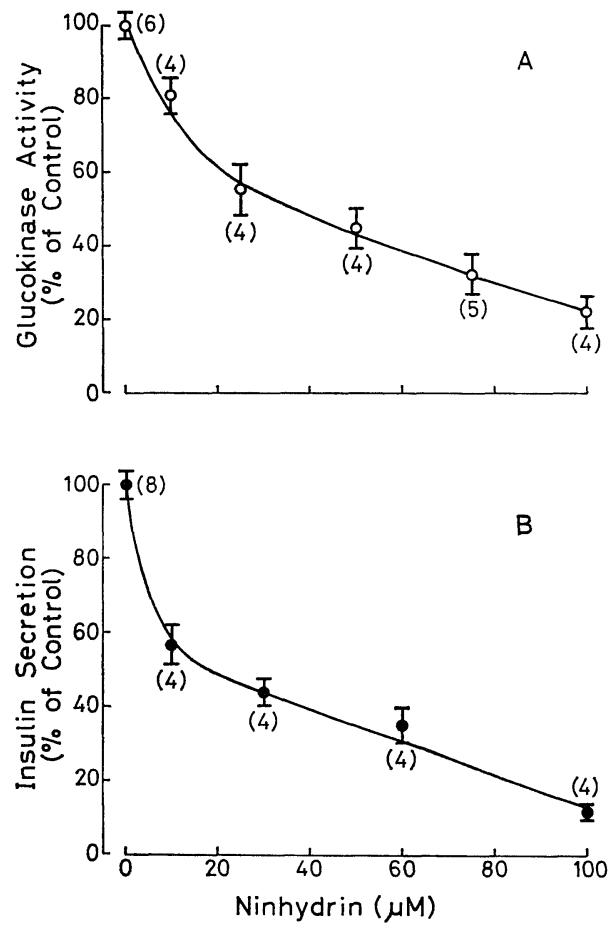

Fig. 2. Effect of ninhydrin concentration on islet glucokinase activity (A) and glucose-stimulated insulin secretion (B). Islets were treated with various concentrations of ninhydrin for $5 \mathrm{~min}$ at $37^{\circ} \mathrm{C}$ and then assayed for glucokinase activity and insulin secretion. Data are expressed as the mean percentage \pm SD of the glucokinase activity and insulin secretion in control islets. The activities of glucokinase and insulin secretion in control islets were $94.7 \pm 3.6 \mathrm{pmol} / \mathrm{h} /$ islet $(n=6)$ and $37.1 \pm 1.4 \mu \mathrm{U} / 40 \mathrm{~min} /$ islet $(n=8)$, respectively.

Table 1. Effect of hexoses on alloxan-induced inhibition of glucokinase activity in pancreatic islets.

\begin{tabular}{lcc}
\hline \multicolumn{1}{c}{ Treatment } & $\begin{array}{c}\text { Glucokinase activity } \\
(\mathrm{pmol} / \mathrm{h} / \text { islet })\end{array}$ & $\%$ of Control \\
\hline Control & $91.2 \pm 3.9(7)$ & 100 \\
Alloxan & $22.2 \pm 2.5(5)$ & 24 \\
Alloxan $+\alpha$-D-glucose & $78.4 \pm 4.6^{*}(5)$ & 86 \\
Alloxan +equilibrated D-glucose & $67.5 \pm 5.6^{*}(4)$ & 74 \\
Alloxan $+\beta$-D-glucose & $58.4 \pm 4.0^{*}(4)$ & 64 \\
Alloxan + D-mannose & $54.7 \pm 2.7^{*}(4)$ & 60 \\
Alloxan +D-galactose & $21.0 \pm 3.2(4)$ & 23 \\
Alloxan+3-O-methyl-D-glucose & $63.8 \pm 5.3^{*}(4)$ & 70 \\
\hline
\end{tabular}

Islets were treated at $37^{\circ} \mathrm{C}$ for $5 \mathrm{~min}$ with $500 \mu \mathrm{M}$ alloxan in the presence or absence of the indicated hexoses $(15 \mathrm{~mm})$ as shown. Glucokinase activity was then measured as described under Materials and Methods. The activity is expressed as the mean \pm SD with the number of experiments in parentheses. $* p<0.001$ as compared with alloxan alone.

Vol. 1, No. 3, 1986 
Table 2. Effect of hexoses on alloxan inhibition of glucose-stimulated insulin secretion.

\begin{tabular}{lcc}
\hline \multicolumn{1}{c}{ Treatment } & $\begin{array}{c}\text { Insulin secretion } \\
(\mu \mathrm{U} / 40 \mathrm{~min} / \text { islet })\end{array}$ & $\%$ of Control \\
\hline Control & $33.9 \pm 2.5(8)$ & 100 \\
Alloxan & $5.8 \pm 0.6(6)$ & 17 \\
Alloxan+-D-glucose & $22.6 \pm 1.0 *(6)$ & 67 \\
Alloxan+D-mannose & $17.2 \pm 2.1 *(6)$ & 51 \\
Alloxan+3-O-methyl-D-glucose & $21.0 \pm 0.9 *(6)$ & 62 \\
\hline
\end{tabular}

Islets were treated at $37^{\circ} \mathrm{C}$ for $5 \mathrm{~min}$ with $500 \mu \mathrm{M}$ alloxan in the presence or absence of the indicated hexoses (15 mM) as shown. The amount of insulin secreted was determined as described under Materials and Methods. The rate of insulin secretion is expressed as the mean $\pm \mathrm{SD}$ with the number of experiments in parentheses. $* p<0.001$ as compared with alloxan alone.

Table 3. Effect of hexoses on ninhydrin-induced inhibition of glucokinase activity in pancreatic islets.

\begin{tabular}{lcc}
\hline \multicolumn{1}{c}{ Treatment } & $\begin{array}{c}\text { Glucokinase activity } \\
(\mathrm{pmol} / \mathrm{h} / \text { islet })\end{array}$ & $\%$ of Control \\
\hline Control & $87.0 \pm 5.6(6)$ & 100 \\
Ninhydrin & $19.1 \pm 2.5(7)$ & 22 \\
Ninhydrin + $\alpha$-D-glucose & $44.4 \pm 3.0^{*}(4)$ & 51 \\
Ninhydrin +-equilibrated D-glucose & $38.3 \pm 2.8^{*}(4)$ & 44 \\
Ninhydrin + $\beta$-D-glucose & $34.8 \pm 1.2^{*}(4)$ & 40 \\
Ninhydrin +D-mannose & $30.5 \pm 2.5^{*}(4)$ & 35 \\
Ninhydrin+D-galactose & $15.7 \pm 1.4(4)$ & 18 \\
Ninhydrin+3-O-methyl-D-glucose & $18.3 \pm 2.4(4)$ & 21 \\
\hline
\end{tabular}

Islets were treated at $37^{\circ} \mathrm{C}$ for $5 \mathrm{~min}$ with $100 \mu \mathrm{M}$ ninhydrin in the presence or absence of the indicated hexoses $(15 \mathrm{~mm})$ as shown. Details are given in the legend to Table 1 . $* p<0.001$ as compared with ninhydrin alone.

Table 4. Effect of hexoses on ninhydrin inhibition glucose-stimulated insulin secretion.

\begin{tabular}{lcr}
\hline \multicolumn{1}{c}{ Treatment } & $\begin{array}{c}\text { Insulin secretion } \\
(\mu \mathrm{U} / 40 \mathrm{~min} / \text { islet })\end{array}$ & \% of Control \\
\hline Control & $33.9 \pm 2.5(8)$ & 100 \\
Ninhydrin & $3.0 \pm 0.2(6)$ & 9 \\
Ninhydrin +D-glucose & $17.4 \pm 1.6^{*}(6)$ & 51 \\
Ninhydrin +D-mannose & $10.0 \pm 1.0^{*}(6)$ & 29 \\
Ninhydrin +3-O-methyl-D-glucose & $3.1 \pm 0.3(6)$ & 9 \\
\hline
\end{tabular}

Islets were treated at $37^{\circ} \mathrm{C}$ for $5 \mathrm{~min}$ with $100 \mu \mathrm{M}$ ninhydrin in the presence or absence of the indicated hexoses $(15 \mathrm{~mm})$ as shown. Details are given in the legend to Table 2 . $* p<0.001$ as compared with ninhydrin alone.

\section{DISCUSSION}

This study has demonstrated that treatment of islets with alloxan at concentrations that inhibit insulin secretion similarly inhibits glucokinase activity. The loss of glucokinase activity is not due to leakage of the enzyme through the 
B-cell plasma membrane, because the activity of cytosolic hexokinase was not lost at all. Thus, as alloxan did not affect the activity of hexokinase, which is known to participate with glucokinase in glucose phosphorylation in islets, the effect of alloxan may be rather selective. Sensitivity of glucokinase to alloxan is not unique to islets, since the glucokinase in hepatocytes is also inhibited by brief exposure of hepatocytes to alloxan as described recently [16].

The following facts suggest that glucokinase is the primary site of alloxan action in the inhibition of glucose-induced insulin secretion. The alloxan concentrations necessary to inhibit the glucokinase activity in islets parallel those necessary to produce alterations in insulin secretion. The alloxan-induced inhibition of glucokinase activity was retained in washed islets following alloxan treatment. Thus, the inhibition of glucokinase activity by alloxan was irreversible as was the case in the inhibition of insulin secretion. Additionally, the inhibition of islet glucokinase activity by alloxan was attenuated by the presence of D-glucose, D-mannose, or 3-O-methyl-D-glucose that protected against the inhibitory action of alloxan on insulin secretion. The order of potencies of hexoses in blocking alloxan inhibition of glucokinase activity (D-glucose $>3-O-$ methyl-D-glucose $>$ Dmannose) was the same as that in preventing alloxan inhibition of insulin secretion. Moreover, the $\alpha$-anomeric preference of the D-glucose effect in preventing alloxan inhibition of glucokinase activity agrees with previous observations $[11,17,18]$ that alloxan inhibition of insulin secretion is more efficiently blocked by $\alpha$-Dglucose than by $\beta$-D-glucose.

The results obtained in parallel experiments using ninhydrin were fundamentally similar to those found with alloxan. Therefore, the inhibition of glucosestimulated insulin release by ninhydrin is also suggested to result from the blocking of glucokinase activity. However, there are a few discrepancies between the two drugs in the influence on pancreatic islets. The concentration $(15-40 \mu \mathrm{M})$ of ninhydrin necessary for half maximal inhibition of both glucokinase activity and insulin secretion was much lower than that $(200-300 \mu \mathrm{M})$ of alloxan. This situation may be partly attributable to a difference in chemical lability between alloxan and ninhydrin under physiological conditions of $\mathrm{pH} 7.4$ and a temperature of $37^{\circ} \mathrm{C}$ [19]; for alloxan was almost completely decomposed during a 5 min incubation at $37^{\circ} \mathrm{C}$ in the medium ( $\mathrm{pH}$ 7.4) used for treatment of islets, whereas the decomposition of ninhydrin was negligible under the same conditions. An alternative explanation is that ninhydrin may be more rapidly and/or more plentifully transported across the B-cell plasma membrane than alloxan, although there is no evidence for this at the present time. Anyway, the mechanisms by which alloxan and ninhydrin inhibit glucokinase should be clarified in order to find a convincing reason for the difference between the two drugs in inhibitory potency. Another discrepancy is that ninhydrin-induced inhibition of both glucokinase activity and insulin secretion was not affected at all by 3-O-methyl-D-glucose, whereas the inhibitory effects of alloxan were effectively protected by the sugar. The protective action of 3-O-methyl-D-glucose against alloxan cytotoxicity in islets was shown to 
result from inhibition of the transport of alloxan across the B-cell plasma membrane [20]. These two facts suggest that the mechanisms of membrane transport of alloxan and ninhydrin may be different from each other. Moreover, the protective effects of D-glucose and D-mannose against alloxan-induced inhibition of glucokinase activity and of insulin secretion were more profound than those against the inhibition by ninhydrin. This may suggest that the inhibitory mechanism of alloxan may not necessarily be the same as that of ninhydrin.

In conclusion, the present study indicates that islet glucokinase may be the critical site at which alloxan- and ninhydrin-induced inhibition of insulin secretion is effected.

This work was supported by a Grant-in-Aid for Scientific Research from the Ministry of Education, Science and Culture of Japan.

\section{REFERENCES}

1. Matschinsky, F.M., Meglasson, M.D., Burch, P.T., Berner, D.K., Najafi, H., Vogin, A.P., Garfinkel, D., and Garfinkel, L. (1983): Glucokinase (ATP: D-glucose 6-phosphotransferase E.C. 2.7.1.2), the glucose sensor of pancreatic islet $\beta$-cells, in Diabetes 1982 (Int. Congress Ser. 600), ed. by Mugola, E., Excerpta Medica, Amsterdam, pp. 337-344.

2. Meglasson, M.D., and Matschinsky, F.M. (1984): New perspectives on pancreatic islet glucokinase. Am. J. Physiol., 246, E1-E13.

3. Miwa, I., Inagaki, K., and Okuda, J. (1983): Preference of glucokinase for the $\alpha$ anomer of hexose: relation to $\alpha$-anomer preference in hexose-induced insulin release by pancreatic islets. Biochem. Int., 7, 449-454.

4. Miwa, I., Hara, H., Okuda, J., Suami, T., and Ogawa, S. (1985): Inhibition of glucose-stimulated insulin release by pseudo- $\alpha$-DL-glucose as a glucokinase inhibitor. Biochem. Int., 11, 809-816.

5. Okuda, J., and Miwa, I. (1986): Metabolic and functional differences among the $\alpha, \beta$ anomers and the aldehyde form of D-glucose. J. Clin. Biochem. Nutr., 1, 189-199.

6. Okuda, J., Miwa, I., Inagaki, K., Ueda, M., and Taketa, K. (1978): D-Glucose anomeric preference of hexokinases in higher animals. J. Biochem., 84, 993-995.

7. Niki, A., Niki, H., Miwa, I., and Okuda, J. (1974): Insulin secretion by anomers of D-glucose. Science, 186, 150-151.

8. Malaisse, W.J., and Sener, A. (1985): Glucokinase is not the pancreatic B-cell glucoreceptor. Diabetologia, 28, 520-527.

9. Sener, A., Leclercq-Meyer, V., Marchand, J., Giroix, M.-H., Dufrane, S.P., and Malaisse, W.J. (1985): Is glucokinase responsible for the anomeric specificity of glycolysis in pancreatic islets. J. Biol. Chem., 260, 12978-12981.

10. Tomita, T., Lacy, P.E., Matschinsky, F.M., and McDaniel, M.L. (1974): Effect of alloxan on insulin secretion in isolated rat islets perifused in vitro. Diabetes, 23, 517-524.

11. Niki, A., Niki, H., Miwa, I., and Lin, B.J. (1976): Interaction of alloxan and anomers of D-glucose on glucose-induced insulin secretion and biosynthesis in vitro. Diabetes, 25, 574579 .

12. McDaniel, M.L., Roth, C.E., Fink, C.J., Swanson, J.A., and Lacy, P.E. (1977): Ninhydrin inhibition of glucose-induced insulin release. Diabetologia, 13, 603-606.

13. McDaniel, M.L., Bry, C.G., Fink, C.J., Homer, R.W., and Lacy, P.E. (1979): Studies on the site of interaction for ninhydrin, alloxan, and D-glucose in insulin secretion by isolated islets in vitro. Endocrinology, 105, 1446-1451. 
14. Lacy, P.E., and Kostianovsky, M. (1967): Method for the isolation of intact islets of Langerhans from the rat pancreas. Diabetes, 16, 35-39.

15. Trus, M.D., Zawalich, W.S., Burch, P.T., Berner, D.K., Weill, V.A., and Matschinsky, F.M. (1981): Regulation of glucose metabolism in pancreatic islets. Diabetes, 30, 911-922.

16. Miwa, I., Hara, H., Matsunaga, H., and Okuda, J. (1984): Inhibition of glucokinase in hepatocytes by alloxan. Biochem. Int., 9, 595-602.

17. McDaniel, M.L., Roth, C.E., Fink, C.J., and Lacy, P.E. (1976): Effect of anomers of Dglucose on alloxan inhibition of insulin release in isolated perifused pancreatic islets. Endocrinology, 99, 535-540.

18. Tomita, T., and Kobayashi, M. (1976): Differential effect of alpha- and beta-D-glucose on protection against alloxan toxicity in isolated islets. Biochem. Biophys. Res. Commun., 73, 791-798.

19. Miwa, I., and Okuda, J. (1982): Non-enzymatic reduction of alloxan by reduced nicotinamide nucleotide. Biochem. Pharmacol., 31, 921-925.

20. Malaisse-Lagae, F., Sener, A., and Malaisse, W.J. (1983): Contrasting modes of action of D-glucose and 3-O-methyl-D-glucose as protectors of the rat pancreatic B-cell against alloxan. Biochim. Biophys. Acta, 762, 36-43. 